\title{
MISSION STATEMENTS OF SOCIALLY RESPONSIBLE FIRMS: A CONTENT ANALYSIS
}

\author{
Refika BAKOĞLU \\ Marmara University, Turkey
}

Bige AŞKUN

Marmara University, Turkey

\begin{abstract}
A well-designed mission statement is essential for formulating, implementing and evaluating business strategy. However the role of the mission statement in the strategic management of business firms has not been sufficiently highlighted in the research literature. The importance of mission statements to the effective strategic management of business organizations is well documented in the literature but it is quite surprising that minimal attention has been paid to the role of mission statements of socially responsible organizations. This paper attempts to fill this gap in the literature. It focuses on the socially responsible firms, which are listed in the Business Ethics' 100 Best Corporate Citizens Index, by selecting the firms whose mission statements could be seen clearly from their corporate websites. The mission statements are then analyzed to determine their components and the differences between the firms.
\end{abstract}

Keywords: Mission Statement, social responsibility, content analysis

\section{INTRODUCTION}

Mission statements are today seen as an important business tool, combining a statement of purpose for the organization with some form of aspirational vision for its future. Undoubtedly, to be effective they do need genuinely to convey the vision of the organization to the organization.

\section{Definitions and Components of Mission Statements}

A mission statement may be a single brief (one or two sentences) statement, or a hierarchy of statements. Sometimes they concentrate on business strategy (focusing on 'aims', 'objectives' or 'targets'), while in others greater weight appears to be given to values, philosophy and ethics. A distinction may be drawn between those targeted at 'internal' stakeholders rather than 'external' ones (Davies and Glaister, 1997;594). In style they can be very vague or very specific and in content aspirational or functional.
It becomes apparent when appraising the some definitions of the mission concept is regarded as multidimensional concept by virtually all authors. Further, variations in conceptualization and the specific words used notwithstanding, it is possible to identify common elements that underlie most definitions of the concept. In contemporary literature especially different mission concept and definition were emphasized. These are (Sidhu, 2003;441):

Company mission is defined as the fundamental purpose that sets a firm apart from the other firms of its type and identifies the scope of its operations in product and market terms (Pearce and Robinson 1991).

Mission is the fundamental purpose and character of the organization e.g. to meet the needs of the mass market in a particular industry (Viljoen 1994).

"Hax and Majluf's definition of the mission is centered on: detecting the changes to be undertaken in business scope and core competencies" ( Hax and Majluf, 1984). Mission statements offer the opportunity for any organization to define clearly the business it is in, state its overall purpose and indicate its uniqueness or distinctive competence (Davies and Glaister, 1997). The first component of the strategic management process is defining the mission and major goals of the organization. The mission sets out why the organization exists and what should be doing (Hill and Jones, 1997).

Management's vision of what the organization seeks to do and to become is commonly termed the organization's mission. A mission statement establishes the organization's future course and outlines 'who we are, what we do and where we're headed' In effect, it sets forth the organization's intent to stake out a particular business position (Thompson and Strickland, 1999). A sense of mission is important because it generates trust and belief in the activities of the organization. It gives meaning to work, motivates people and fosters consensus activities conducive to the achievement of organizational goals. A mission statement provides a unifying force, a sense of direction and a guide to decision- making for all levels of management (Kemp and Dwyer, 2003;636). 
The mission statement should describe the organization's main activities and the position it wishes to attain in its industry. There should be a statement of the key values of the organization, particularly regarding attitudes towards stakeholder groups and the ethical agenda. The organization should have the intention and capability to live up to the mission statement, so, desirably, it should articulate expected behavioral standards ( Johnson and Scholes, 1999;243).

The component of mission statement is defined in the related literature as follows.

\section{TABLE 1 THE COMPONENT OF THE MISSION STATEMENT}

\begin{tabular}{|c|c|}
\hline AUTHORS & COMPONENT OF THE MISSION STATEMENT \\
\hline Ackoff, 1987;30 & $\begin{array}{l}\text { 1.Values } \\
\text { 2.Beliefs } \\
\text { 3.Guidelines for the way the organization conducts its business and determines its } \\
\text { relationships with its stakeholders }\end{array}$ \\
\hline Pearce and David 1987;109 & $\begin{array}{l}\text { Customers: Who are the organization's customer } \\
\text { Products/services: What are the organization's major products or services? } \\
\text { Location/markets: Where does the organization compete? } \\
\text { Technology: Is technology a primary concern of the organization? } \\
\text { Concern for survival, growth and profitability: Is the organization committed to } \\
\text { economic objectives? } \\
\text { Philosophy: What are the basic beliefs, values, aspirations and philosophical pri- } \\
\text { orities of the firm? } \\
\text { Self - concept: What is the organization's distinctive competence or major compet- } \\
\text { itive advantage? } \\
\text { Concern for public image: Is the organization responsive to social, community and } \\
\text { environmental concerns? } \\
\text { Concern for employees: Are employees considered to be a valuable asset of the } \\
\text { organization? }\end{array}$ \\
\hline David, 1989 & $\begin{array}{l}\text { 1.Purpose } \\
\text { 2.Philosophy } \\
\text { 3.Beliefs } \\
\text { 4.Business principles } \\
\text { 5.Business definition }\end{array}$ \\
\hline Campbell and Yeung, 1991;10 & $\begin{array}{l}\text { 1.Company purpose, } \\
\text { 2.Strategy } \\
\text { 3.Shared values } \\
\text { 4.Behavior standards }\end{array}$ \\
\hline Piercy and Morgan, 1994;2 & $\begin{array}{l}\text { 1.The central purpose or philosophy of the organization, } \\
\text { 2.Business definition or the product - market domain where the organization is to } \\
\text { operate, } \\
\text { 3.Core values or what do we want people in this organization to be good at? } \\
\text { 4.Critical success factors or what do we have to be good at to succeed in this mar- } \\
\text { ket or industry? }\end{array}$ \\
\hline $\begin{array}{l}\text { The Ashridge Model } \\
\text { (Davies and Glaister,1997;595) }\end{array}$ & $\begin{array}{l}\text { 1.Purpose ( 'why the company exists'); } \\
\text { 2.Strategy ('the competitive position and distinctive competence'); } \\
\text { 3.Values (what the company believes in'); } \\
\text { 4.Behavior standards ('the policies and behavior patterns that underpin the distinc- } \\
\text { tive competence and value system'). }\end{array}$ \\
\hline Vern McGinnis (David, 1999) & $\begin{array}{l}\text { 1.Define what the organization is and what the organization aspires to be, } \\
\text { 2.Be limited enough to exclude some ventures and broad enough to allow for cre- } \\
\text { ative growth, } \\
\text { 3.Distinguish a given organization from all others, } \\
\text { 4.Serve as a framework for evaluating both current and prospective activities and } \\
\text { 5.Be stated in terms sufficiently clear to be widely understood throughout the organ- } \\
\text { ization }\end{array}$ \\
\hline David, 2001 & $\begin{array}{l}\text { 1.Organization's purpose, } \\
\text { 2.Products and services, } \\
\text { 3.Markets, } \\
\text { 4.Philosophy and basic technology }\end{array}$ \\
\hline
\end{tabular}




\section{Why Have a Mission Statement?}

Mission Statements offer the opportunity for any organization to define clearly the business it is in, state its overall purpose and indicate its uniqueness or distinctive competence (Davies and Glaister, 1997;594). Many authors have noted the importance of the mission statement for directing and guiding organizational strategy. The value of mission statements as an internal marketing tool has also been recognized. Internal stakeholders, managers and other employees need a reference point to explain the purpose and philosophy of the organization. In this way they can help ensure a consistent corporate direction throughout larger organizations (Tolle, 1988; Davies and Glaister, $1997 ; 595)$. Indeed it has been suggested that the value of mission statements in many organizations is primarily as an internal tool, assisting managers to assert their leadership and provide motivation for employees (Klemm, Sanderson and Luffman, 1991; Davies and Glaister, 1997;595).

The importance of mission statements to the effective strategic management of business organizations is well documented in the literature. A mission statement is a general expression of the overriding purpose of an organization that, ideally, is in line with the values and expectations of major stakeholders. Mission statements are often regarded as 'enduring statements of purpose that distinguish one business from others'. The mission statement is a declaration of an organization's "reason for being". It answers the pivotal question, "What is our business?" A clear mission statement is essential for effectively establishing objectives and formulating strategies (David, 1999). Some theorists regard the organization's mission as a 'cultural glue' which enables it to function as a collective unit. This 'cultural glue' consists of strong norms and values that influence the way in which people behave, how they work together and how they pursue the goals of the organization (Campbell and Yeung, 1991; 10). A well - designed mission statement is essential for formulating, implementing and evaluating business strategy (David, 2001).

Few mission statements identify profit or any other financial indicator as the sole purpose of the firm. Indeed, most do not even mention profit or shareholder return. Employees of organizations or departments are usually the mission's most important audience. For them, the mission should help to build a common understanding of purpose and commitment to nurture. Profit maximization not only fails to motivate people but also does not differentiate between organizations.
Every corporation wants to maximize profits over the long term. A good mission statements, by addressing each principal theme, must communicate why an organization is special and different. Two studies that linked corporate values and mission statements with financial performance found that the most successful firms mentioned values other than profits. The less successful firms focused almost entirely on profitability. In essence, profit is the metaphorical equivalent of oxygen, food and water that the body requires. They are not the point of life, but without them, there is no life (Dess, Lumpkin and Taylor, 2004).

Campbell and Yeung $(1991 ; 12)$ emphasizes that the process of developing a mission statement should create an "emotional bond" and "sense of mission" between the organization and its employees.

Mission statements are presumed to have numerous advantages for companies. This may explain why they are so popular despite the lack of agreement about their purpose and content. Four of the most frequently cited advantages are (Bartkus, Glassman and McAfee, 2000; 24):

1. To communicate a sense of the firm's direction and purpose. Some feel that only by having a mission statement can a firm develop coherent short and long range goals, objectives and plans. By reading a firm's mission statement, employees, stockholders and customers will know where the firm is headed.

2. To serve as a control mechanism to keep the firm "on track." Mission statements help keep a firm from wandering into unrelated businesses and pursuing unrelated objectives. They serve as boundary lines for making decisions.

3. To help in making a wide range of day -today decisions. When new or non routine decisions need to be made, mission statements can be used as decision criteria, steering employees in the right direction.

4. To inspire and motivate employees. Mission statements give meaning to work and provide a shared sense of purpose. They help workers realize the broader purpose of their efforts and encourage them to place that purpose ahead of their own self - interests.

The purpose of mission statement should be to communicate a description of the firm that allows current and prospective employees, suppliers, investors and customers to determine whether they want to be involved with it.

Every large firm in the world has developed a web site, yet little is known about how these firms use their sites to communicate business strategy information, 
especially mission statements. This information is important because since the 1980s, firms have relied on mission statements (Vander Weyer,1994; 66) to organize and communicate strategy-related information to stakeholders (Campbell,1997; 931;Rigby,1998;56). Ireland and Hitt, (1992; 34) assert that the purpose of mission statements is to publicly declare the purpose, goals, product /markets and philosophical views of the organization.

\section{RESEARCH DESIGN, METHODOLOGY AND FINDINGS \\ Objectives of The Research}

The main aim of the research is to observe whether the mission statements of socially responsible firms have certain patterns that may differ them from the ones that are not considered socially responsible. For that reason, the main aim of the research will be to categorize and name the pattern that may emerge within the mission statements of socially responsible firms. The second objective of the study is to observe the degree to which socially responsible firms include values and principles in their clearly stated mission.

\section{Limitations of The Study}

Three limitations are present and need to be considered when interpreting the results of the research. First of all, the information and messages released online by organizations are one-sided declarations, and it is not guaranteed that they are applied and realized in the real life. This may limits the generalizability of the study. Taking into consideration this point, we limit our research with only the mission statement of the socially responsible firms, rather than including values, principles and social responsibilities and codes of conducts etc. If the latter important enough to the company, they should also be included in their mission statements. This is to say that by limiting our research within the mission statement, we party overcome with the practice problem since this limitation allow us to observe whether stated values, principles and social responsibilities important enough to the firms.

Second limitation in this study is about the measurement of the information gathered. The "contents" of the online mission statements provided and the "frequency" of the items are the most important information this study bases on. This type of evaluation may disregard the weight and importance of the information provided.

Lastly and most importantly, it should be noted that main limitation of the research comes from the operational definition of the socially responsible firms. Socially responsible firms are defines as the ones which listed in the "Business Ethics' 100 Best Corporate Citizens" list, and be listed for at least last 5 years. We, as researchers, think being listed once in the list, should not be enough to be considered as socially responsible. Firms should be in the last regularly and currently in order to be considered as socially responsible.

\section{Validity of The Research}

To ensure validity of the research, Reliability is semantic validity has been taken into account. Semantic validity exists when people familiar with the texts examine lists of themes placed in the same category and agrees that these words have similar meanings (Weber, 1990). Since in the content analysis process, each researcher independently and individually categorized the items of mission statements, and the independent sorter examined the themes, made discussions and the themes have been placed under same categories with an agreement on a final categorization, this research has the semantic validity.

\section{Sampling Method and Size}

The population of this study is composed of socially responsible corporations of the global market. The socially responsible firms were selected from the "100 Best Corporate Citizens 2004" listing of the Business Ethics Magazine, USA. (http://www.businessethics.com/100best.htm). As mentioned earlier, the operational definition of the socially responsible firms is the ones, which is listed in the list for last 5 years. Taking the definition into consideration, it can be claimed that population of the research is only 29 corporations (see Table 2 for the complete list). As it can be clearly seen form the table 1 , only 12 out of 29 companies had their mission statement clearly stated on their web sites. In this research, the 12 companies are considered as samples. Intel Corporation has also the mission statements of their each business units. Since no clearly stated mission statement is available as a general mission statement of the company, it is also left out of the sampling list in the research. The companies that are not listed in the sampling list have icons titled as values, principles, social responsibilities, codes of conduct etc. on their web sites. Although these components can be considered as a part of the mission statements, we, as researchers, prefer not to include them in the sampling list since one of the objectives of the research is to observe whether stated vales and principles are important enough to the socially responsible firms by looking at their clearly stated mission state- 
TABLE 2 COMPANIES LISTED IN THE 100 BEST CORPORATE CITIZENS LIST BETWEEN 2000-2004.

\begin{tabular}{|l|l|l|}
\hline LISTEN NO. & NAME OF THE COMPANIES & MISSION STATEMENT IN THE WEB SITES \\
\hline $\mathbf{1}$ & Fannie Mae & Not clearly stated \\
\hline $\mathbf{2}$ & Procter \& Gamble & Not clearly stated \\
\hline $\mathbf{3}$ & Intel Corporation & Sated only for the SBUs \\
\hline $\mathbf{4}$ & St. Paul Companies & Not clearly stated \\
\hline $\mathbf{6}$ & Deere \& Company & Not clearly stated \\
\hline $\mathbf{7}$ & Avon Products, Inc. & Clearly stated \\
\hline $\mathbf{1 0}$ & Hewlett-Packard Company & Not clearly stated \\
\hline $\mathbf{1 2}$ & Ecolab Inc. & Not clearly stated \\
\hline $\mathbf{1 4}$ & IBM & Not clearly stated \\
\hline $\mathbf{1 7}$ & Herman Miller, Inc. & Not clearly stated \\
\hline $\mathbf{1 9}$ & The Timberland Company & Not clearly stated \\
\hline $\mathbf{2 2}$ & Cisco Systems, Inc. & Clearly stated \\
\hline $\mathbf{2 4}$ & Southwest Airlines Company & Clearly stated \\
\hline $\mathbf{2 7}$ & Motorola, Inc. & Not clearly stated \\
\hline $\mathbf{3 1}$ & Cummins Inc. & Clearly stated \\
\hline $\mathbf{3 2}$ & Adolph Coors Company & Not clearly stated \\
\hline $\mathbf{3 3}$ & Modine Manufacturing Company & Clearly stated \\
\hline $\mathbf{4 3}$ & Clorox Company & Not clearly stated \\
\hline $\mathbf{4 4}$ & AT\&T & Not clearly stated \\
\hline $\mathbf{4 5}$ & Pitney Bowes Inc. & Clearly stated \\
\hline $\mathbf{4 8}$ & Starbucks Coffee Company & Clearly stated \\
\hline $\mathbf{4 9}$ & Merck \& Co., Inc. & Clearly stated \\
\hline $\mathbf{5 3}$ & Graco Inc. & Not clearly stated \\
\hline $\mathbf{5 7}$ & Brady Corporation & Clearly stated \\
\hline $\mathbf{6 3}$ & Medtronic, Inc. & Clearly stated \\
\hline $\mathbf{7 4}$ & The New York Times Company & Clearly stated \\
\hline $\mathbf{8 9}$ & Golden West Financial Corp. & Not clearly stated \\
\hline $\mathbf{9 8}$ & Sonoco & Clearly stated \\
\hline & Whirlpool Corporation & Not clearly stated \\
\hline
\end{tabular}

ments on their World Wide Web sites.

Each firm's "Home page" was accessed using the web address provided by www.google.com. After examining each firm's "Home page" to determine the presence or absence of a mission - type statement or a link to one, we then clicked on the firm's "About us " ( or similar ) page and likewise examined it.

\section{Type of Research and The Unit of Analysis}

The research is an exploratory qualitative research in its nature since the research objectives are not investigated much in the literature, and content analysis is chosen as a research method considering the objectives. Content analysis is a necessary tool in the study as purpose of the research is to explore and observe the patterns that may emerge in the mission statements of the socially responsible firms, and to observe the degree to which socially responsible firms include values and principles in their clearly stated mission by collecting data from their corporate web sites. Secondly, the data collected from the corporate web sited needed to be systematically categorized in order to categorize items of mission statements and make presumptions on them. The research method that would best fit this process of systematic information collection and analysis of items of mission statements is content analysis as content analysis is a research method that uses a set of procedures to make valid presumptions from the text (Weber, 1990). Since the central idea of content analysis is to classify many words in texts into much fewer content categories; it is the most suitable technique for drawing a model out of rich texts on corporate web sites.

Content analysis technique requires an objective, systematic and quantitative description of the evident content of communication (Zimmer and Golden, 1988). In order to conduct a thorough content analysis, these rules have been cautiously respected and applied in this research. The objectivity is supplied when the researcher and the independent sorter obtained the same results from the same data. A systematic analysis is obtained when the 
inclusion or exclusion of categories are done in a consistent manner in order to avoid biases of the researchers.

In this research, the unit of analysis is corporate web sites, which means that the corporate information was collected from the web sites of companies. In fact, corporations can use many communication means to provide information on themselves in our ages; TV, radio, newspapers, periodicals and corporation magazines are some of those communication mediums. However, as telecommunications technologies develop, the Internet has generated intense interest among communications professionals. Today, there is a wide agreement that the Internet and the World Wide Web have become important communication media for corporations (Esrock and Leichty, 1998). Corporate web sites can be accepted as corporate signatures and provides valuable information that is available worldwide.

\section{STAGES OF THE CONTENT ANALYSIS AND THE FINDINGS \\ Content Analysis Stages}

Content analysis method has two main types of computer-aided and human-coded content analyses (Weber, 1990). In the research, human-coded content analyses is done, as few companies are included in the sampling list, and the research did not look for specific words or terms in texts. Rather than using predetermined coding sheet, researchers created a coding sheet for the analysis, a new list of items observed in the mission statements. Afterwards researchers create broader categories using the list of items. As can be

\section{TABLE 3 THE STAGES OF CONTENT ANALYSIS}

\section{Stage 1 \\ CONTENT ANALYSIS OF CORPORATE WEB SITES IS DONE. THE THEMES ARE SHAPED.}

\section{Stage 2}

THE RESEARCHER GROUPS THE THEMES INTO CATEGORIES.

\section{Stage 3}

ONE INDEPENDENT SORTER GROUPS THE THEMES INTO CATEGORIES.

\section{Stage 4}

THE RESEARCHER AND THE INDEPENDENT SORTER DISCUSS THE CATEGORIES. FINAL CATEGORIES AND DIMENSIONS ARE SHAPED.

Stage 5

ONE JUDGE GROUPS THE THEMES UNDER THE FINAL CATEGORIES. seen in Table 3, content analysis of the research has five stages:

As the first step, each researcher content analyzed the mission statements of 12 socially responsible companies individually. At this stage, mission statements components are divided according to theoretical background part of this paper, and items that are related with the business are excluded while value and principle related items included. This is done for the reason: first, companies in the sampling list is from different businesses, that is why differences stem from that point would have any place in the research. When business related items were connected to the social responsibility approach of the firms, than they were added to the coding sheet. Second, according to the second objective of the research, values and principles that is clearly mentioned in the mission statements has to be analyzed. At the next step, the researcher grouped the items into mutually exclusive and exhaustive categories. On the other hand, the independent sorter grouped the themes into mutually exclusive and exhaustive categories. After this, the researcher and the independent sorter discussed the reasoning behind their classification and agreed on final 5 categories and their sub-items. As the last step, two judges were asked to group the themes under the agreed categories. One of the researchers specialized on strategic management is functioned as an independent sorter for this research. This person had previous experience with the content analysis technique. One professor of management is asked to be judge for the analysis. The judge is familiar with the subject.

\section{Findings of The Content Analysis}

This study showed that only $41 \%$ of the socially responsible companies that are recognized as socially responsible companies for last 5 years had clearly stated mission statements. Although most of the companies in the list had values, principles, social responsibilities written in their web pages only 12 companies had mission statements icons on their corporate web pages. Table 4 presents quantitative summary of the results of the content analysis. As can be seen at the table, there were 5 dimensions and 32 sub-items in total. 5 dimensions that emerge in the content analysis are expected considering the related literature. What is eye catching with the result is the fact that not many items occurred more than once in each dimension, and although all the companies are listed in social responsibility index for the last five years, their mission statements do not really indicate and prove that they are very much concern about social responsibility con- 
TABLE 4 SUMMARY OF THE RESULTS OF THE CONTENT ANALYSIS

\begin{tabular}{|c|c|c|c|}
\hline & DIMENSIONS & $\begin{array}{l}\text { ITEMS OCCURRED MORE THAN } \\
\text { ONE INTHE MISSION STATEMENTS }\end{array}$ & $\begin{array}{l}\text { NUMBER OF ITEMS } \\
\text { IN EACH DIMENSION }\end{array}$ \\
\hline 1 & Customer & Customer satisfaction (3 times) & 8 \\
\hline 2 & Employee & $\begin{array}{l}\text { Advancement opportunities (4 times) } \\
\text { Safety (twice) } \\
\text { Equal opportunity for learning (twice) } \\
\text { Equal opportunity personal growth (twice) } \\
\text { Respect, care and concern (twice) } \\
\text { Respect for diversity (twice) }\end{array}$ & 8 \\
\hline 3 & Shareholder & Shareholder return (3 times) & 5 \\
\hline 4 & Community/ Society & $\begin{array}{l}\text { Integrity (twice) } \\
\text { Honesty (twice) } \\
\text { Good corporate citizenship ( } 3 \text { times) }\end{array}$ & 8 \\
\hline \multirow[t]{2}{*}{5} & Environment & None & 3 \\
\hline & TOTAL & & 32 \\
\hline
\end{tabular}

sidering social responsibility literature and items that occur in their mission statement (please see table 4). One may claim that they have written concerns, values and principles related with their social responsibilities separately in their web sides. Although figuring out how rich is their values, principles and social responsibility concerns compare to the related literature is another research question to be explored, just because they are not stated in their mission statement it causes doubt about sincerity of their concern, even though under the assumption that their values, principles and social responsibility concerns are rich in their substance.

\section{RESULTS AND DISCUSSIONS}

As table 5 clearly shows, most of the items occurred once or some of them twice or some of them three times in each dimensions. This basically indicates that we cannot really observe certain patterns in the mission statements of socially responsible firms, which is related social responsibility concern of the firms. We can also hardly say that even the dimensions that are indicated in this research did not really emerge. This is to say that no general conclusion can be made out of these results, and every company should be considered individually. The only thing which is clear here is the fact that stated values, approaches and concerns related with social responsibility in the mission statements of the "accepted" socially responsible firms are not rich in their substance.

Considering operational definition of mission in this research, it should be noted here that it is contrary and surprising to explore that socially responsible, at least "socially responsible accepted", companies do not emphasize values, principles and philosophy related to their social responsibility approaches as much as expected. Although it is observed that social responsibility has become one of the main ingredients of strategic architecture of transnational companies (Bakoğlu, 2003), it still need time until it become real substance for sustainable competitive advantage of companies as it is evident in the content analysis research of this paper. As some recent studies stress that there is still long time until social responsibility become a sustainable development tool in reality and would be a sound ground for social policy of governments, and companies in the literature (Frankental, 2001; Bakoğlu and Kaya, 2003; Bakoğlu, 2004).

Lastly, it should be stressed that the reason why the "accepted socially responsible firms' mission statements are so poor in their substance related with social responsibility issues, is related to the origins of the companies that are mainly from the USA, as according to the corporate governance approach of The USA originated companies, governance mechanism expected to present shareholder's collective interest (Hitt, Ireland and Hoskisson, 2005; 306, Ülgen and Mirze, 2004 ; 424). In our research, only one company stress- 
TABLE 5 ITEMS EMERGED IN THE MISSION STATEMENTS OF SOCIALLY RESPONSIBLE COMPANIES

\begin{tabular}{|l|l|c|}
\hline DIMENSIONS & ITEMS & FREQUENCY \\
\hline \multirow{5}{*}{ Customer } & Safety & 1 \\
\hline \multirow{5}{*}{ Employee } & Security & 1 \\
\cline { 2 - 3 } & Customer needs & 1 \\
\cline { 2 - 3 } & Customer respect and loyalty & \\
& Respect, care and concern for customers & 1 \\
\cline { 2 - 3 } & Customer satisfaction & 3 \\
\cline { 2 - 3 } & Lifelong customer relationship & 1 \\
\hline & Meaningful work for employees & 1 \\
\cline { 2 - 3 } & Advancement opportunities for employees & 4 \\
\cline { 2 - 3 } & Safety/ safe workplace & 2 \\
\cline { 2 - 3 } & Equal opportunity for learning & 2 \\
\cline { 2 - 3 } & Equal opportunity personal growth & 2 \\
\cline { 2 - 3 } & Respect, care and concern for employees & 2 \\
\cline { 2 - 3 } & Employee satisfaction & 1 \\
\cline { 2 - 3 } & Respect for diversity & 2 \\
\hline Shareholders & Investor's return & 1 \\
\cline { 2 - 3 } & Wealth for all stakeholders & 1 \\
\cline { 2 - 3 } & Shareholder return & 4 \\
\cline { 2 - 3 } & Fair profit & 1 \\
\cline { 2 - 3 } & Work environment with respect and dignity & 1 \\
\hline Environment & Quality of life & 1 \\
\cline { 2 - 3 } & Integrity & 2 \\
\hline & Honesty & 2 \\
\cline { 2 - 3 } & Commitment to excellence & 1 \\
\hline & Contribute positively to our communities & 1 \\
\cline { 2 - 3 } & Socially responsible & 1 \\
\cline { 2 - 3 } & Diversity & 1 \\
\cline { 2 - 3 } & Good corporate citizenship & 1 \\
\hline & Environmental stewardship & 2 \\
\cline { 2 - 3 } & Contribute positively to our environment & 1 \\
\cline { 2 - 3 } & Cleaner, healthier, safer environment & \\
\hline
\end{tabular}

es stakeholder interest although shareholder wealth were mostly stresses in the mission statements. On one side this verifies the related literature, on the other this should be taken as a sign that similar researches to a larger extent. For example, originally German, Japanese, Chinese, Russian etc. companies should be included in the sample for the new research. 


\section{REFERENCES}

Bakoğlu, R. (2004), "Could Codes of Conduct be a Sustainable Development Policy for the EU's Enlargement Process?", The Third International Symposium On Business Administration on The Future of the EU Competitive Power after the EU Enlargement, Biga, Çanakkale, 27-28 May.

Bakoğlu, R. and Kaya, S. (2003), "Changing Strategic Architecture of Multinational Firms: The Case of Textile and Apparel Industries", the GBATA 2003 International Conference, Budapest, 8-12 July.

Bartkus, B., Glassman, M. and Mcafee, B. (2002), Do large European, US and Japenese Firms Use Their Web Sites To Communicate Their Mission ?, European Management Journal, Vol.20,No.4, pp.423-424

Bartkus, B., Glassman, M. and Mcafee, B. (2000), Mission Statements: Are They Smoke and Mirrors? Business Horizons, November - December.

Campbell, A. (1997), Mission Statements, Longe Range Planning, 30 (6), pp.931-932

Campbell, A. and Yeung, S. (1991), Creating a sense of Mission, Longe Range Planning, 24 (4), pp.10-20.

David, F.R. (1989), How Companies define Their Mission, Long Range Planning, 30, pp.594-604

David, F.R. (1999), Strategic Management Concepts, Prentice Hall, 7th edition, USA.

David, F.R. (2001), Strategic Management Concepts, Upper Saddle River, 8th edition, NJ.

Davies, S. W. and Glaister, K. W. ( 1997), Business School Mission Statements - The Bland leading The Bland ?, Long Range Planning, 30 (4), pp.594-604

Dess, G, Lumpkin, G,T, Taylor, M,L (2004), Strategic Management, Mc Graw Hill, North America.

Drucker, P. F. (1973), Management: Tasks, Responsibilities and Practices, Harper and Row, NY

Esrock, S. L. and Leichty, G. B. (1998), "Social Responsibility and Corporate Web Pages: Self Presentation or Agenda Setting?", Public Relations Review, Vol. 24 (3).

(http://www.business-ethics.com/100best.htm)
(March - April 2005).

Frankental, P. (2001), Corporate Social Responsibility - A PR Invention?. Corporate Communications: An International Journal, 6(1), pp.18-23.

Hitt, M. A., Ireland, D. R. and Hoskisson, R. E. (2005), Strategic Management: Competitiveness and Globalization, Thomson South-Western Publication, 6th Edition, Mason, Ohio.

Johnson, G. and Scholes, K. (1999), Exploring Corporate Strategy, Prentice Hall London, 5th edition, London.

Kemp, S. and Dwyer, L. (2003), Mission Statements of International Airlines: A Content Analysis, Tourism Management, 24, pp.635 -637.

Klemm, M, Sanderson, S and Luffman, G (1991), Mission Statements: Selling corporate values to employees, Longe Range Planning, 24 (3).

Ülgen, H. and Mirze, K. (2005), İşletmelerde Stratejik Yönetim, Literatür Yayınları, İstanbul.

Pearce, J, A. and David, F. (1987), Corporate Mission Statements: The Bottom Line, Academy of Management Executive, I ( 2 ), pp.109-116.

Rigby, R. (1998), Mission Statements, Management Today, March, pp.56 -59.

Sidhu, J. (2003), Mission Statements: Is It Time To Shelve Them?, European Management Journal, Vol.21, No.4, pp 440-441.

Strickland, T. ( 1999), Strategic Management, Mc Graw Hill, 11th edition, Singapore.

Tolle, E. F. (1988), Developing The Mission Statements, Organizational Development Journal, Spring.

Vander Weyer, M. (1994), Mission Improvable: for Clinched Syntactically -Challenged Copy Mission Statements are Hard to Beat, Management Today, September, pp.66-68.

Weber, R. P. (1990), Basic Content Analysis, Sage Publications, London.

Zimmer, M. R. and Golden, L. L. (1988), Impressions of Retail Stores: A Content Analysis of Consumer Images, Journal of Retailing, Vol. 64, Fall. 